\author{
Marie Bojsen-Møller, Sune Auken, Amy J. Devitt \\ \& Tanya Karoli Christensen
}

\title{
Illicit Genres: The Case of Threatening Communications
}

Tidsskriftet Sakprosa

Bind 12, Nummer 1

(C) 2020

10.5617/sakprosa. 7416

M. Bojsen-Møller, S. Auken,
A. J. Devitt \& T. K. Christensen
$1 / 53$
Sakprosa.no 


\section{Resumé}

Denne artikel anlægger et nyt perspektiv på studiet af sproglige trusler ved at argumentere for at de kan karakteriseres som en genre - en genre der generelt giver stærke konnotationer til intimidering, frygt, aggression, magt og tvang. Vi kombinerer Retoriske Genrestudiers (RGS') teoretiske ramme med resultater fra teoretiske og empiriske analyser af trusler for at nå frem til en mere nuanceret og fyldestgørende forståelse af trusler. Sproglige trusler er som udgangspunkt ikke at finde i gængse oversigter over genrer, og man lærer heller ikke om dem i skolen. Derfor designede vi et spørgeskema der skulle teste hvor genkendelige trusler egentlig er. Selvom trusselsforskere rapporterer at trusler har en bemærkelsesværdig variation i deres formmæssige og kontekstuelle træk, kategoriserede størstedelen af vores respondenter testemnerne som trusler, på trods af at de ikke fik præsenteret nogen tekstuel, kontekstuel eller layoutmæssig ramme for fortolkningen. Dette indikerer at truslen er en genkendelig genre. Vi argumenterer for at truslen hører under en bredere kategori af illegitime genrer: genrer der generelt set har skadelige eller ubehagelige konsekvenser for samfundet, og som almindeligvis påvirker deres ofre negativt. Den måde illegitime genrer tages op på i samfundet, deres uptake, adskiller sig meget fra hvordan andre genrer tages op. De der benytter illegitime genrer, undgår ofte aktivt at navngive dem, hvilket indebærer at de grupper der reagerer på illegitime genrer, på ganske betydelig vis er med til at definere dem. Dette studie bidrager til forskning i sproglige trusler, idet genreteori kaster lys over vigtige situationelle faktorer der påvirker fortolkningen af en tekst som en trussel dette er et særligt omstridt spørgsmål i forhold til trusler der er indirekte formuleret. Studiet bidrager også til genreteori ved at pege på et nyt område genreforskere kan undersøge, nemlig illegitime genrer. Undersøgelser af illegitime genrer har også bredere samfundsmæssig relevans da de belyser forskellige slags problematisk, retorisk opførsel der kan have destruktive

M. Bojsen-Møller, S. Auken,
A. J. Devitt \& T. K. Christensen
$2 / 53$
Sakprosa.no 
konsekvenser for det enkelte menneske og for den demokratiske samfundsorden bredt set.

\section{Abstract}

This study takes a novel approach to the study of threatening communications by arguing that they can be characterized as a genre - a genre that generally carries strong connotations of intimidation, fear, aggression, power, and coercion. We combine the theoretical framework of Rhetorical Genre Studies (RGS) with results from theoretical and empirical analyses of threats to arrive at a more comprehensive perspective of threats. Since threats do not form part of any regular curriculum of genres, we designed a survey to test how recognizable they are. While scholars on threats describe threatening communications as remarkably varied in form and contextual features, the majority of our respondents categorized test items as threats without prompts of any kind, indicating that threats are a recognizable genre. We propose that threatening communications belong to a wider category of illicit genres: i.e. genres that generally disrupt and upset society and commonly affect their targets negatively. The uptakes of illicit genres are very different from those of other genres, as the users of the genres often actively avoid naming them, making uptake communities significant shapers of illicit genres. The present study contributes to research on threatening communications, since genre theory sheds light on important situational factors affecting the interpretation of a text as a threat - this is a particularly contentious question when it comes to threats that are indirectly phrased. The study also contributes to genre theory by pointing to new territory for genre scholars to examine, namely illicit genres. Studies of illicit genres also have wider, societal benefits as they shed light on different kinds of problematic rhetorical behavior that are generally considered destructive or even dangerous.

M. Bojsen-Møller, S. Auken,
A. J. Devitt \& T. K. Christensen 
Nøgleord: sproglige trusler; illegitime genrer; genrestudier; uptake; voldeligt sprog.

Keywords: threatening communications; illicit genres; genre studies; uptake; violent communication.

\section{About the authors}

Marie Bojsen-Møller is a PhD candidate at the project Understanding Threats: Language and genre that is funded by the Carlsberg Foundation (CF17-0907) and housed by the University of Copenhagen, Department of Nordic Studies and Linguistics, Copenhagen, Denmark. She has previously researched authorial distance in paratexts in selected works by Søren Kierkegaard and Vladimir Nabokov, and her current areas of research are Forensic Linguistics and genre from a Rhetorical Genre Studies perspective. Her most recent article is "Sproglige virkemidler i indirekte trusler”, co-authored with Tanya Karoli Christensen (Aarhus Universitet, 2019). ORCID: http://orcid.org/o000-0001-7864-8526

Sune Auken is Dr. phil. habil and Associate Professor of Danish Literature at the University of Copenhagen, Department of Nordic Studies and Linguistics, Copenhagen, Denmark. He is a literary scholar specializing in interpretation, genre and cross-disciplinary work. He most recently co-edited the anthology Genre in the Climate Debate together with Christel Sunesen (De Gruyter, forthcoming 2020). He is part of the project Understanding Threats: Language and genre. ORCID: http://orcid.org/0000-0002-1749-6028

Amy J. Devitt is Chancellors Club Teaching Professor and Professor of English at the University of Kansas, Department of English, Lawrence, KS, USA. She specializes in rhetoric and composition and English language studies,

M. Bojsen-Møller, S. Auken,
A. J. Devitt \& T. K. Christensen
$4 / 53$
Sakprosa.no 
particularly rhetorical genre studies. Her most recent book is Landmark Essays on Rhetorical Genre Studies, co-edited with Carolyn R. Miller (Routledge, 2018). Her current interests focus on the cultural meaning and impact of genres (or kinds of writing) and how uncovering those meanings can contribute to personal and social change. She is part of the project Understanding Threats: Language and genre. Web of Science ResearcherID J-7996-2013, ORCID https://orcid.org/o0oo-0001-8815-6218

Tanya Karoli Christensen is Associate Professor of Danish Language and Linguistics at the University of Copenhagen, Department of Nordic Studies and Linguistics, Copenhagen, Denmark. She is principal investigator of the project Understanding Threats: Language and genre, funded by the Carlsberg Foundation (CF17-0907). She specializes in the grammar of written and spoken Danish and employs corpus linguistic and sociolinguistic methods to examine the use and functions of mood and modality. Her current research focuses on the language of threats and hate speech. One of her most recent articles is "Indirect threats as an illegal speech act" (Aarhus Universitet, 2019). ORCID: http://orcid.org/o00o-0001-8108-1110

M. Bojsen-Møller, S. Auken,
A. J. Devitt \& T. K. Christensen
$5 / 53$
Sakprosa.no 


\section{Illicit Genres: The Case of Threatening Communications ${ }^{1}$}

\section{Introduction}

Threatening communications have become an increasing concern of private, public, and political life. Our highly digitized societies afford a multitude of easily available channels through which threats can be communicated, both directly to targets through email, chat or text messages, or more obliquely about targets on different social media platforms. ${ }^{2}$ Threatening communications are not only emotionally stressful for targets, but are also a challenge for the law enforcement and judicial systems that have to handle them, and they pose problems for society in general by polluting the public sphere with negative and destructive sentiments.

Threatening communications occur in many different situations, both in and out of the public eye: for instance, in debates on social media where language gets heated and tempers flare over a disagreement on a current, hot topic; in organized crime where gangs threaten each other in order to gain monopoly over an area's drug sale; or in stalking cases where continued, unwanted contact can evolve into more or less disguised death threats. 3 With public debates stifled by threats, and private people and public figures frightened or even endangered by them, the need to understand threats is more pertinent now than it has ever been.

\footnotetext{
${ }^{1}$ The authors gratefully acknowledge the funding by the Carlsberg Foundation, and we give our special thanks to all presenters at the University of Copenhagen Symposium on Illicit genres (November 2019). We also appreciate the valuable and helpful comments of the anonymous reviewers.

${ }^{2}$ See, for example, https://www.bristolpost.co.uk/news/bristol-news/abuse-threats-madegreta-thunberg-3897936.

3 In some instances, the situations that involve stalking and threatening communications can even lead to physical harm (Smith, 2019).
}

M. Bojsen-Møller, S. Auken,
A. J. Devitt \& T. K. Christensen
6 / 53
Sakprosa.no 
Scholars on threat have primarily examined threatening communications from an applied perspective (e.g. Gales, 2015b; Napier \& Mardigian, 2003; Smith, 2006) because of the risk that the threat contained in them can be realized. However, even if a threat is not carried out, it is still a verbal act of violence or assault. In many countries, threats constitute a criminal offense in and of themselves, because of the severe effects they can have on their victims. However, basic research on the generic features of threatening communications is scarce (but see Gales, 2010, 2011; Muschalik, 2018; Nini, 2017), and has mostly been conducted in an Anglo-American setting (but see Artmann, 1996; Christensen, 2019; Christensen \& Bojsen-Møller, 2019). It is therefore important that we gain insight into what makes these heterogeneous actions one recognizable genre - a threat.

Based on authentic, Danish examples, this article examines the genre of threatening communications from the perspective of Rhetorical Genre Studies (RGS), an approach that defines genre as social action. RGS enables us to investigate the typified in the recurrent situations (Miller, 1984) that threatening communications are part of, in other words to look at the typical and recurring aspects of threats. Even if threats are a heterogeneous genre that can occur in different contexts, have different purposes, effects, and uptakes (Freadman, 1994, 2002), where forms of threats accordingly vary (Limberg, 2009; Muschalik, 2018; Storey, 1995), they share one common social function, which is to intimidate the receiver of the threat (Christensen \& Bojsen-Møller, 2019; Fraser, 1998; Gales, 2010; Olsson, 2004; Walton, 2000).

Despite the heterogeneity of threats, we argue that threats are a highly recognizable genre. We have conducted a survey that provides evidence that average people can recognize - and even label - threats even though they are different in form. We propose that this recognizability is caused by 'tacit' knowledge of the genre (Freedman, 1994), perhaps particularly strong

M. Bojsen-Møller, S. Auken,
A. J. Devitt \& T. K. Christensen 
because of its antagonistic power structure and confrontational nature as an 'antisocial' act (Storey, 1995, p. 74).

Threatening communications thus constitute what we term an illicit genre. Illicit genres do not originate from an official institution, and they rarely emerge from a coherent discourse community (Swales, 2016) or a specific community of practice (de Grot, 2008; Pogner, 2005; Wenger, McDermott \& Snyder, 2002), which means that they are not officially regulated in the ways that many institutional genres are. A distinguishing trait of illicit genres is that they are socially and sometimes even legally proscribed. 4 Most studies within RGS have been conducted on genres that are generally socially accepted. Studying this illicit genre, threats, extends not just our understanding of threats but also our understanding of genres since our study applies RGS to a genre that appears to be more heterogeneous than typified, that is recognizable, though not attached to a single discourse community, community of practice or rhetorical situation. This adds another realm to which RGS can contribute: genres not authorized, administered, institutionalized, or generally accepted in society, but rather illicit.

In the same way, Nordic studies of non-fiction prose genres ('nordisk sagprosaforskning') has up until now mostly focused on constructive, edifying or knowledge-building genres (cf. Tønnesson, 2012; 2017) that either emerge from institutional settings or from everyday situations. 5 Conversely, illicit

\footnotetext{
4 There have been discussions on benign vs. malicious threats (see Walton \& Macagno, 2007), but it is beyond the scope of this article to decide on whether the mostly benign "threats" or "warnings" that come from people with institutionally or socially conferred authority can beor in fact are - seen as threats. One example could be a parent telling their children that they cannot have dessert if they do not clean up their room; another could be a teacher telling their students that they will fail the class if they do not hand in their essays.

5 For instance, dissertations, dictionaries, legislation, personal letters, diaries and many more (e.g. Grepstad, 1997). Though, some Nordic studies in rhetoric or linguistics have been conducted on less harmonious genres, such as hate speech (e.g. Millar, 2019; Nilsen, 2014), incitement to crime (Larsen, 1973) and political dissent (e.g. Villadsen, 2017).
}

M. Bojsen-Møller, S. Auken,
A. J. Devitt \& T. K. Christensen
$8 / 53$
Sakprosa.no 
genres are not perceived as constructive, edifying, or knowledge-building, but rather as destructive, dangerous and damaging. The concept of illicit genres contributes to research on Nordic non-fiction prose genres by inviting studies of genres that have harmful or adverse functions, or genres that emerge from occluded fora or communities.

As genre analyses are highly complex and entail different communicative aspects, they are often multi-method studies (cf. Randazzo, 2015). This study combines a theoretical approach with both survey results and speech act, linguistic, and rhetorical analyses. We lay the theoretical foundations by reviewing key concepts from RGS that are particularly relevant when seeking to understand the genre of threats. Then we outline how threats have been categorized as a speech act and point to the aspects that need further complicating. Combining the insights from theories on threats and empirical studies of threats with the knowledge of genres from RGS, we approach the question of what the salient, recurrent traits of this highly varied genre are. Based on results from the survey, we argue that threats are in fact a recognizable genre, despite differences in form and in degrees of directness and indirectness. Subsequently, we propose the term illicit genre as a cover term for a wider array of genres, including threats, hate speech, harassment and grooming. Finally, we sum up our findings and discuss the implications of this new concept for rhetorical genre theory and our understanding of nonfiction prose genres.

\section{Genre as Social Action}

RGS approaches genre from a functional rhetorical perspective. In her pioneering article "Genre as Social Action”, Carolyn Miller defines genre as "typified rhetorical actions based in recurrent situations" (1984, p. 159). Miller emphasizes the importance of function and context in relation to form and

M. Bojsen-Møller, S. Auken,
A. J. Devitt \& T. K. Christensen
$9 / 53$
Sakprosa.no 
substance when interpreting meaning. $R G S$ hence sees genre as social action, as a functional activity that accedes to - but also interacts with - the social requirements and norms of a recurrent situation. Genres are thus a mixture between recurrent (the typical or generic) and new (Miller, Devitt, \& Gallagher, 2018).

In her view of "meaning-as-action" (1984, p. 159), Miller is inspired by speech act theory (Searle, 1969), the notion that our utterances perform actions that have real, social consequences. Whereas speech act theory seems largely oblivious to genre theory (Freadman, 2002), genre scholars have discussed the placement of speech acts within the frames of genre theory. Bazerman relates speech acts to the function of texts:

Each successful text creates for its readers a social fact. The social facts consist of meaningful social actions being accomplished through language, or speech acts. These acts are carried out in patterned, typical, and therefore intelligible textual forms or genres, which are related to other texts and genres that occur in related circumstances (Bazerman, 2004, p. 311).

Many well-known genres are performed by utterances that combine several speech acts (as when a job application contains both a greeting, an expression of a wish to be considered for the job, several assertions about the candidate's qualifications, etc. etc.). In other circumstances, a genre can be instantiated by an utterance consisting of just one speech act, as when we greet an acquaintance on the street or text a partner that we are late. In other words, speech acts can be considered as the specific forms that a genre took on a particular occasion.

M. Bojsen-Møller, S. Auken, 
A crucial addition to this picture comes from Freadman (2002). In a Bakhtinian vein, Freadman's central argument is that the traditional notion of speech acts is reductive because it overlooks the complexity of diachronic and synchronic interrelations to other situationally relevant speech acts, i.e. speech acts that were prior to, coexist with, or that are even possible alternatives to the one performed in the here and now. In distinction to this, Freadman argues that genre as social action is always embedded in a rich social history of actual as well as alternative actions that together inform our understanding of what takes place and how we can respond to it, how we can 'take it up' (Freadman, 1994, 2002). But not only that, uptakes (which are themselves genres that may be instantiated as utterances, performing one or more speech acts) respond to certain aspects of prior actions and thereby define with a sort of backwards causality what genre that prior action represented:

The important thing to note here is that uptake depends on a step that is not specified in speech-act theory. This is the step in which our uptake selects, defines, or represents its object. [...] Uptake is first the taking of an object; it is not the causation of a response by an intention. This is the hidden dimension of the long, ramified, intertextual memory of uptake: the object is taken from a set of possibles (Freadman, 2002, p. 48).

Genre theory thus emphasizes the socially, contextually and historically complex aspects of discourse, where speech act theory typically stays within the confines of an isolated speech situation (see also section 3 on the difference between a speech act approach and a genre approach).

Genre is a metadiscursive notion, and therefore, it is not possible to approach genre as such; we only meet genres in their instantiations in individual

M. Bojsen-Møller, S. Auken,
A. J. Devitt \& T. K. Christensen
11 / 53
Sakprosa.no 
utterances (Auken, 2015, p. 157). However, we still recognize utterances as an instance of or in relation to a given genre, which must mean that we draw parallels between utterances, because we perceive something as being recurrent. Bakhtin's notion of written or spoken speech genres as "typical forms of utterances" (1986a, p. 63) are visibly present in the works of many $R G S$ scholars (see, for instance, Freadman 2002; 2020, Freedman \& Medway, 1994; Reiff \& Bawarshi, 2016). The boundaries of an utterance are delimited solely by "a change in speaking subject” (Bakhtin, 1986a, p. 71). As such, an utterance can consist of one simple word or sentence, representing one speech act, or even a whole text, representing several.

One of the distinguishing characteristics of utterances is addressivity (Bakhtin, 1986a, p. 99). An utterance is always addressed to someone, as opposed to the grammatical unit sentence, which can be studied in isolation, without any situational context. Bakhtin explains that "[t]he various typical forms this addressivity assumes and the various concepts of the addressee are constitutive, definitive features of various [written or oral] speech genres" (1986a, p. 99). This entails that the typical relationships, including the typical power relations, between sender (what Bakhtin calls 'author') and addressee are very important aspects for a genre and thus for the recognizability of a genre.

Every utterance interacts with and responds to previous utterances; it is in a dialogic relationship with other utterances that Bakhtin calls a historical interrelation (1986b, p. 106). It is a link in "a very complexly organized chain of other utterances" (Bakhtin, 1986a, p. 69). ${ }^{6}$ The combination of this historic interrelation and the chain of utterances may be a source of recurrence that

\footnotetext{
${ }^{6}$ Bakhtin discusses the "dialogic relationships among texts and within the text" (1986a, p. 105), which has influenced later works on intertextuality.
}

M. Bojsen-Møller, S. Auken,
A. J. Devitt \& T. K. Christensen
12 / 53
Sakprosa.no 
helps create recognizability. One might say that we recognize utterances and their functions because they are instantiations of genres.

Every utterance or instantiation of a genre is in a dialogic relationship with former utterances, which means that every utterance has aspects that are perceived as typical (the recurrent, the generic) and aspects that add something new, thus re-accentuating the former utterances and renewing the genre. That this chain of utterances is 'complexly organized' points to the fact that genres are not fixed categories with little room for individual contribution. They are "simultaneously firm and flexible" (Auken, 2018, p. 17), and only "stabilized for now" or "stabilized enough" (Schryer, 1993, p. 204)— or even, with a more radical integration of Bakhtin, "not even stabilized for now, as they live and breathe through individual instances and interactions across and within genres" (Devitt, 2009, p. 39).

Every individual instantiation of a genre is an uptake on earlier instantiations of the genre, an uptake on the situation within which it functions, and also an uptake on other genres, since genres constantly interact and intertwine with other genres. Freadman discusses uptake in terms of "generic boundar[ies]" (2002, p. 43), since we often understand genres by comparing them to or contrasting them with other genres: 7

When we respond to an utterance or text, we take it as a certain genre. 'Is that a threat or a promise?' we might ask, in order to respond 'in kind'. Of course, we may not ask explicitly, and we may misconstrue the act, in which case the dialogue may take a meta-

7 Note here that the French word genre means 'a kind'.

M. Bojsen-Møller, S. Auken, 
discursive detour to renegotiate its bases (Freadman, 2012, p. $555)$.

Threats are often compared to promises, as both are commissive speech acts that propose a future act (see further in section 3). The greatest difference between the two genres is that the future act of promises is positive in nature, while the future act of threats is negative in nature. Thus, the genres that a given genre is compared with and contrasted to are highly significant (cf. the notions of 'not-statements', Freadman, 1994, and 'not genres', Reiff \& Bawarshi, 2011, referring to denials of similarity between a given genre and other genres), since they give information about the way the genre is being used and understood. In that way, uptake signals and contributes to the recognizability of a genre.

Genres are social constructs, and as such, they are (re)constructed, recognized, understood and named - i.e., taken up - by the users of language and genres. Genres emerge from "recognizable, self-reinforcing forms of communication", and they "arise in social processes of people trying to understand each other well enough to coordinate activities and share meanings for their practical purposes" (Bazerman, 2004, p. 316-317). Genre memory or recognition occurs despite heterogeneity in form, content, or contexts. Threats are treated as a genre and taken up by different specific groups: for example by law enforcement, by the judicial system, by journalists who write about threat cases, by victims of threats, and by scholars who examine threats.

\section{Theory on Threats}

Scholars on threats have often focused on the heterogeneity of threats, and Storey emphasizes how interwoven threats are with their individual contexts: "because the interaction of language and context is inherently and ultimately

M. Bojsen-Møller, S. Auken,
A. J. Devitt \& T. K. Christensen
$14 / 53$
Sakprosa.no 
unpredicatable (Sic.), it is surprisingly - if not impossibly - difficult to construct a context-independent definition of 'threat"' (1995, p. 74). However, we know some aspects of what is typical of threats or what makes threats recognizable as a genre, not least from speech act theory about threats. However, other aspects of threats still need further consideration. Fraser's definition of the speech act of threatening is often cited within a branch of linguistics that considers threats from a forensic angle (e.g. Gales, 2010; Muschalik, 2018; Shuy, 1996; Solan \& Tiersma, 2005):

[F]or speakers to issue a threat successfully they must intend to express by way of what is said 1. the intention to personally commit an act (or to see that someone else commits the act); 2. the belief that the results of that act will affect the addressee in an unfavourable way; 3 . the intention to intimidate the addressee through the awareness of the intention in 1. (Fraser, 1998, p. 171)

Fraser looks at threats from a classical speech act perspective (Austin, 1962; Searle, 1969) and, as Searle, he classifies threats as commissive speech acts. Above, Fraser outlines the felicity conditions ${ }^{8}$ for a threat. He specifically examines the illocutionary act of threatening, thereby stressing the intent of the speaker, as opposed to examining the perlocutionary effect of threatening, i.e. the effect on the hearer. The speaker must intend to communicate that they wish to perform a future act, which they believe is detrimental to the hearer in an effort to intimidate the hearer (Fraser, 1998). Fraser underlines that it is not necessary for the hearer in fact to feel threatened, because the intention to intimidate is enough: "Inherent in every threat is the intention to send fear into the addressee" (1998, p. 161). 9 However, intent is extremely

\footnotetext{
${ }^{8}$ I.e. the conditions that must be in place for a speech act to be in effect (Austin, 1962).

9 Fraser gives the following example to highlight this fact: If you believe someone to be allergic to a certain flower, and you threaten to bring them a specimen of that flower, you have communicated a threat even if they are in fact not allergic to it (1998, p. 161).
}

M. Bojsen-Møller, S. Auken, 
difficult to assess; it is a psychological state and as such not directly accessible for anyone besides the speaker. This is particularly contentious in a legal setting (Fuller, 2015; Hurt \& Grant, 2019; Muschalik 2018; Schauer, 2003), where the consequences can be especially wide-reaching. Threateners can possibly create reasonable doubt regarding the meaning, the primary illocutionary force, of their communicated words. By being deliberately ambiguous and indirect, they can allow themselves a recourse to plausible deniability (Pinker, Nowak \& Lee, 2008; Solan \& Tiersma, 2005; Walton, 1996, 2000). When understanding or analyzing an indirect threat (Christensen \& Bojsen-Møller, 2019; Gingiss, 1986; Limberg, 2009; Yamanaka, 1995), it is therefore necessary to look at the immediate context of the threat, including its uptakes.

Christensen and Bojsen-Møller (2019) shift the focus from the intent of the speaker to the function of the threat itself. They refer to the Danish Criminal Code, section 266, which states that threats can 'be fit' to cause fear. Along the same lines, Christensen and Bojsen-Møller define a threat as an attempt to intimidate someone by directly or indirectly communicating that they will be subject to a future, undesirable course of events, for which the threatener takes responsibility in some way. The three crucial aspects of a threat are thus futurity, harm, and sender responsibility, aspects that generally correspond with Fraser's definition. Importantly, Christensen and Bojsen-Møller stress the fact that the indication of harm as well as the assignment of responsibility for the threatened action does not need to be presented directly but can be implied, i.e. phrased indirectly or left out completely.

The common function of threats, whether they are direct or indirect, is to cause fear - to intimidate - and this is the case even though it might not always be the conscious or declared intent of the speaker. Intent is not intersubjectively verifiable, whereas function is an assessment of how an

M. Bojsen-Møller, S. Auken,

A. J. Devitt \& T. K. Christensen $16 / 53 \quad$ Sakprosa.no 
utterance works (see further in section 4.2). Function is therefore of greater consequence than intent when considering threats as a genre. When Fraser looks at threats from a speech act perspective, he considers how the act of threatening is done felicitously: When will something count as an attempt to utter a threat? What are the intentions and beliefs of the threatener? Notice that these are both conditions that "cannot be observed or measured by an external analyst" (Muschalik, 2018, p. 10). However, when we study threats from a genre perspective, we look at the aspects that are recognizable because they occur repeatedly and saliently (i.e., the recurrent aspects), and we look at the individual context within which a given threat functions. What does the threat do, what role does it play in which context, what are the typified versus unique aspects of the social action it performs, and what are its uptakes?

\section{The Whole and the Part: Threats as Social Action}

Thus, in order to understand a genre, it is important to consider the whole and the parts (Devitt, 2009) of the recurrent pragmatic actions and situations - to consider the typical, and also to consider the specifics of the individual genre instantiations, as individual instantiations of a genre will vary. As threats are such a highly heterogeneous genre, it means that we have to work to see that it is a recognizable genre, instead of looking to see the variation. We must establish the salient features of threats before we can consider the variation that the genre subsumes. Consequently, in this article, we focus less on the variability evidenced by individual threatening communications and more on their recurrent traits. Understanding the social action of a genre means considering both its forms, exigencies (Bitzer, 1968; Miller, 1984), purposes, inherent power relations (Paré, 2002), functions, effects, and uptakes. In the following three subsections, we consider these aspects as they typically pertain to threats.

M. Bojsen-Møller, S. Auken,
A. J. Devitt \& T. K. Christensen
$17 / 53$
Sakprosa.no 


\subsection{Form}

Genre is not a means of creating "closed classifications" (Miller, 1984, p. 153) of discourse based primarily on form, and the RGS-tradition has prioritized the functional role of genre. However, the formal aspects are still important, and many RGS studies of actual genre use indeed rely on an understanding of formal characteristics of groups of utterances (e.g. Devitt, 2016; Nyboe, 2016; Schryer, 2002; Segal, 2007; Winsor, 2000). “Any complete understanding of genre will need to include the language forms that serve to achieve [its] purposes and effects, the forms that make generic action happen" (Devitt, 2009, p. 27; see also Auken, 2015). While forms of threatening communications have been shown to vary greatly (see e.g. Fraser, 1998; Limberg, 2009), some patterns of form are typical of threats. Below are some of the salient linguistic features in threats, indicating futurity, harm, and sender responsibility (cf. section 3 ).

- futurity: prediction modals (Gales, 2010, p. 168-173; Muschalik, 2018, p. 74; Nini, 2017, p. 110. E.g. 'will', 'be going to'; they can also be indicative of intention); present tense with future reference (Muschalik, 2018, p. 70-72); and expressions denoting a time frame (Gales, 2010, p. 98-99. E.g. 'soon', 'next week').

- harm: violent verbs (Gales, 2010, p. 96-98; Muschalik, 2018, p. 83. E.g. 'kill', 'shoot', 'blow up', 'hurt', 'die', 'be dead').

- sender responsibility: modals of intent (Gales, 2015a, p. 194. E.g. semimodals 'want' and 'need'); first person pronouns (Gales, 2010, p. 102; Muschalik, 2018, p. 102-104; Nini, 2017, p. 110. E.g. 'I', 'we', 'me').

M. Bojsen-Møller, S. Auken, 
Of course, the use of first person pronouns is not in itself an indication of sender responsibility, but it "can give information on, for example, the level of involvement of a speaker" (Muschalik, 2018, p. 100), and if they occur as a grammatical subject with an active (possibly violent) action verb, it does indicate sender responsibility (Christensen \& Bojsen-Møller, 2019). Gales (2010, p. 98) and Nini (2017, p. 110) also found second person pronouns to be indicative of threatening language. ${ }^{10}$ Explicit addressivity (the mentioning of both sender and receiver) thus seems to be a particularly important aspect of threats (cf. section 2, see further in section 4.2).

Through a survey examining student ideologies about threats, Gales found five linguistic features to be "most commonly associated with threatening language - profanity, action verbs of harm, second person pronouns, modals of intent, and time frame" (2010, p. 98, our italics). Interestingly, Gales' corpus studies demonstrate that particularly profanity is much less frequent than expected from lay (and professional11) perceptions. These student ideologies give us indirect insight into how people perceive the genre of threats. Another way of examining perceptions of genres is detailed in this article's section 5 , where we explain the design and results of our survey that sought to elicit average people's categorizations of instantiations of threats and other genres.

Threats are often divided into direct, indirect, and conditional threats (Gales, 2010; Napier \& Mardigian, 2003), and threat scholars often strongly associate threats with conditional language ('if you don't do A, then I will do B’) (Kent, 1967; Limberg, 2009; Milburn \& Watman, 1981; Salgueiro, 2010; Walton, 2000). However, conditional threats can be issued both directly and

${ }^{10}$ They found a significantly higher frequency of both second and first-person pronouns in threatening texts compared with non-threatening texts.

${ }^{11}$ Most of the student ideology categories overlap with views that practitioners have of threats (Gales, 2010).

M. Bojsen-Møller, S. Auken, 
indirectly. Gales' (2010) survey on students' ideologies about threats showed that students believe conditional threats to be the most frequent of the three types (conditional 54\%, indirect 37\%, direct 9\%). ${ }^{12}$ However, only $26 \%$ of the threats in Gales' corpus were in fact conditional, the majority being indirect (62\%), and the minority being direct (12\%). In the same way, conditional language was only found in $28.9 \%$ of the threats in Muschalik's (2018) corpus, and only $37 \%$ of the threats in Nini's (2017) corpus were conditional, the majority again being indirect (59\%), and only $4 \%$ being direct. Conditionality does not seem to be as prominent a feature in threats as many scholars and students assume, but it is nonetheless part of people's generic idea of what a threat is. We follow Muschalik (2018) in assessing threats on a spectrum from direct to indirect. Below are examples of a direct (1) and an indirect (2) threat:

(1) Du dør snart. Jeg kommer og skyder dig i nat. ${ }^{13}$

'You'll die soon. I'm coming to shoot you tonight.'14

(2) Vi lever stadig. Du er stadig vores mål. Og vi skal nok nå det. Vi ses jo nok om lidt ${ }^{15}$

'We are still alive. You are still our target. And we shall certainly'16 get

\footnotetext{
${ }^{12}$ This is interesting since conditional language was not one of the linguistic features they most associated with threats.

13 Facebook message sent to Danish politician, who has given us permission to use it in our research. All examples in the article are our translations. All data donators in our project have signed written consent forms.

14 The Danish Jeg kommer og skyder (direct translation *I come and shoot) is translated into the progressive form in English 'I'm coming to shoot'. There is no direct English equivalent to the Danish grammatical phenomenon concord construction, where two verb phrases agree in tense (here present tense), and where both verb phrases have the same reality value (here both kommer 'come' and skyder 'shoot' fall under the category realis) (Nielsen, 2011). Thus, the Danish original expresses more clearly that the shooting will 'actually' occur (Palmer, 2001) than the English version does, as the infinitive 'to shoot' has no reality value.

${ }_{15}$ Text message quoted in a Danish higher court judgment found in Karnov. Karnov is an online database of Danish laws and court judgments

${ }_{16}$ The meaning of the Danish epistemic particle nok ranges from certainty to probability, depending on context (Christensen, 2007). Together with skal 'shall', nok expresses certainty, so it is here translated into 'certainly'.
}

M. Bojsen-Møller, S. Auken, 
there. As you know ${ }^{17}$, we'll probably ${ }^{18}$ see you in a bit'

In example (1) both futurity (present tense with future reference, ${ }^{19}$ temporal adverbials snart 'soon' and i nat 'tonight'), harm (verbs of death or violence dør 'die', skyder 'shoot'), and sender responsibility (1SG Jeg 'I' + active action verb) are expressed directly. In example (2), however, only futurity (modal present skal nå 'shall get', ses 'will see'20, temporal adverbial om lidt 'in a bit'), and sender responsibility (1PL $v i$ 'we' + active action verb) are stated, whereas the possible harm to the receiver is to be inferred. Consequently, the threat is indirect, even if the implications of the word mål 'target' are easy to grasp. Sometimes both futurity, harm, and sender responsibility will have to be inferred either from the context or from cultural knowledge of formulaic ways of threatening, as in 'I know where you live' (see example in section 5), which has almost become a cliché threat.

\subsection{Exigence, Purpose, Power Relation, and Function}

The exigence of a genre, or rhetorical exigence, is a social demand or "widely shared, recurrent need" (Miller \& Shepherd, 2004, p. 157) that can be "allayed

\footnotetext{
${ }_{17}$ The Danish dialogic particle jo has no English lexical equivalent. jo can signal consensus, but also the opposite "in situations where the speaker is trying to force a sense of consensus onto the interlocutor" (Mortensen, 2012, p. 239). The threat in (2) is enforced by the use of jo as it here forces an unwanted consensus.

${ }_{18}$ Nok here expresses probability.

19 There is no modal verb in the Danish original Du dør snart, which literally translated would be *`You die soon', so in our English translation, the future reference of the verb phrase is created by the modal present 'will die'. The futurate present progressive is not used in Danish (e.g. 'am coming (to shoot)'). Instead, future reference is shown by either modal present or simple present with future reference. In Danish, the progressive aspect can be imitated in formulations like 'kommer og skyder'.

${ }^{20}$ In Danish, ses is present tense with future reference, while the English translation 'will see' is modal present.
}

M. Bojsen-Møller, S. Auken, 
through the mediation of discourse" (Miller, 1984, p. 152). ${ }^{21}$ Threats are a "socially defined genre with strong ideological links to stances of violence and threatener control" (Gales, 2011, p. 28). We therefore characterize the generic exigence of threats as a need to exert power over someone else.

The individual purposes or reasons for this need to exert power will of course differ:

Threats can be made for a wide variety of reasons - to vent anger, to instill fear, to cause a desired result, to challenge authority, to attract attention, to save face, to show intent of purpose, to further negotiations, or to provide humor (Gales, 2010, p. 9).

These individual reasons are not directly accessible for external analysts; we cannot access the "actual, but [only] the 'plausible' intentions" (Muschalik, 2018, p. 129).

However, when considering the typical addressivity of threatening communications, we can observe different power relations between threatener and victim that can shed light on some of the possible reasons for the recurrent need to exert power. Often, threats are seen as a tool for powerful people to keep their powerful position (cf. Limberg, 2009), but we also see many examples of threats coming from people who are not in a particularly powerful position (e.g. threats from ordinary citizens aimed at celebrities, politicians, or authorities deciding their fates). They are not trying to uphold an already existing position of power over someone else, but rather act from a

\footnotetext{
${ }^{21}$ Exigence is defined as "an imperfection marked by urgency; it is a defect, an obstacle, something waiting to be done, a thing which is other than it should be" (Bitzer, 1968, p. 6). The saliency of "exigence" as a fundamental topic in genre research is picked up for discussion by Freadman (2020).
}

M. Bojsen-Møller, S. Auken, 
position of powerlessness. To utter a threat can then be an attempt to shift a power relation (e.g. when people threaten their former partners as an attempt to regain power), as well as to enforce an already existing power relation. Power is thus inherent to the genre of threats, not merely external to it (cf. Muschalik, 2018. Also see Gales, 2010). The function of genres is fundamentally to "help people do things in the world" (Devitt, 2004, p. 13-14), and given the right circumstances, the genre of threats help people exert power over and intimidate other people.

Exigence and function are similar concepts that both approach the question of 'why' from a different view than purpose does, as Miller (2015) explains:

Purpose poses the question from an actor's point of view: why are you doing this? What is your aim or goal? [...] In contrast, exigence, or what we might more generally term function, poses the question from a system's point of view: why does this happen? what does it achieve not only for any actors or agents involved but also for the stability and viability of the rest of the system? (p. 175)

Function is, in Miller's words, more general than exigence. Assessing the function of a genre is assessing the whole and the parts of the generic situations (also see Harder, 2006, p. 96, on the notion of function in functional linguistics). How does the genre generally work? It is not only a question of how it is generally intended to work, but also of how it is generally taken up.

The common function of threats, then, is to intimidate someone (Fraser, 1998; Gales, 2010; Olsson, 2004; Walton, 2000) in order to exercise power over them or cause fear. This common function is assessed not only by considering the recurrent need to exert power and intimidate, but also by considering

M. Bojsen-Møller, S. Auken, 
the recurrent uptake of intimidation and fear (see further in section 4.3). However, intimidation can either be a means of achieving another goal, i.e. to regulate the behavior of someone, ${ }^{22}$ or intimidation can be the goal in itself. We often see online threats that have no directive illocutionary force, and therefore nothing the receiver of the threat can do to change the situation. Many of them seem to be sent out of pure frustration or 'emotional discharge' (Muschalik, 2018. Cf. Limberg, 2009). ${ }^{23}$

Similarly, Muschalik finds two main functions for the threats in her dataset: manipulation and retaliation. ${ }^{24}$ Manipulative threats have both a commissive and a directive force; they express a commitment to a future act by the sender and a command for the receiver. They use "a threat to either coerce the target into doing something or refrain from doing it in the future" (Muschalik, 2018, p. 131), and the threat is therefore a means to achieve an end. Manipulative threats happen prior to the event that the threatener desires, and are therefore called pre-event threats. Below is an example of a manipulative threat that seeks to make the receiver refrain from doing an act:

- HOLD Dig FRA ALLAN / ELLER DU SKAL DØ / DET ER ALVOR / HAN ER MiN og / KuN MiN / FAT DET 'STAY AWay FROM ALLAN / OR YOu WILL DIE / I MEAN IT / HE IS MiNE and / OnLY MiNE / GET IT'25

\footnotetext{
22 E.g. to extort someone for money or favors, to stop someone from pursuing a planned course of action, or to force them to perform an unwanted action.

${ }^{23}$ Not to mention so-called 'trolls' who seem to find pleasure in causing pain (Buckels, Trapnell, \& Paulhus, 2014).

${ }_{24}$ As indicated in the texts themselves and in the metadata available about the specific situations.

25 Extract from handwritten note, Engelhardt \& Lund, 2008. Engelhardt and Lund (2008, 2009) consist of threatening messages from the Danish National Police archives. The editors selected the messages that they found the most interesting, and as such, they cannot be taken as representative of Danish threats in general.
}

M. Bojsen-Møller, S. Auken, 
In this conditional threat, both the desired behavior ('stay away from Allan') and the possible sanction ('or you will die') are directly stated.

All conditional threats are by nature manipulative, but even threats "that only specify a kind of desired behavior" (Muschalik, 2018, p. 131) without directly clarifying the possible sanction also have a manipulative function. Below is an example of this:

- HiT MED ALLE PENGENE! / IKKE ET ORD ! / KUN SEDLER TAK! / TAK FOR DEJLIG SAMMEN ARBEJDE ! / MiG. (tyv)

'GiVE ME ALL THE MONEY! / NOT A WORD ! / ONLY BILLS

PLEASE ! / THANK YOU FOR YOUR LOVELy COOPERATION ! / Me. (thief)'26

Here, only the desired behavior is mentioned ('give me all the money! Not a word'), but the possible sanction has to be inferred from the immediate situational context (the note was given to a staff member at a Post office during an attempted robbery).

Retaliative threats have no direct or indirect indication of a desired behavior of their receiver, but only a direct or indirect indication of a sanction. Instead of having a clear manipulative goal, "it seems that speakers react to past events and refer to these events as justifications of their own actions or as having triggered or provoked a form of punishment" (Muschalik, 2018, p. 132).

Contrary to manipulative threats, retaliative threats occur post-event. Below is an example of a retaliative threat:

${ }^{26}$ Handwritten note, Engelhardt \& Lund, 2008.

M. Bojsen-Møller, S. Auken,

A. J. Devitt \& T. K. Christensen $25 / 53 \quad$ Sakprosa.no 
- $\quad$ E,,,,,,,,JEG FINDER DIG OG NÅR JEG GØR SÅ ER DU SATME FARDIG MED AT GÅ RUNDT OG SPILLE LAEKKER;;;;;;;;;;DET DU GJORDE VED MIG ER TOTAL FORKERT OG HAR GJORT MIG TIL DEN JEG ER IDAG OG TRO MIG NÅR JEG SIGER AT DU HAR EN STOE REGNING HER DER BETALES:::::::::: 'E,,,,,,,,I WILL FIND YOU AND WHEN I DO YOU ARE DAMN WELL DONE WALKING AROUND ACTING ALL HOT;;;;;;;;;; WHAT YOU DID TO ME IS TOTAL WRONG AND HAS MADE ME INTO WHO I AM TODAY AND BELIEVE ME WHEN I SAY THAT YOU HAVE A BIC BILL THAT IS PAID::::::::::, ${ }^{27}$

In this threat, there is apparently nothing the receiver can do to change the situation, no desired behavior, because the threat is caused by something the receiver has already done ('what you did to me'). Instead, there is an indirectly phrased indication of a sanction ('I'll find you and when I do you're damn well done walking around acting all hot').

If retaliative threats seek to manipulate the receiver, the manipulation is emotional rather than physical (Muschalik, 2018), which corresponds with the notion that threats are an act of intimidation, whether their desired effect is intimidation only or as a means to attain something.

\subsection{Effect and Uptake}

The most commonly discussed effects of threats are fear (Christensen \& Bojsen-Møller, 2018; Fraser, 1998; Gales, 2010; Olsson, 2004) and - in

27 Facebook message. Danish higher court judgment found in Karnov. Spelling errors in the Danish original have been given approximate equivalents in the English translations.

M. Bojsen-Møller, S. Auken,

A. J. Devitt \& T. K. Christensen $26 / 53 \quad$ Sakprosa.no 
threats that involve some kind of coercion ${ }^{28}$ - sometimes also a compliance with the directive illocution (Kent, 1967; Milburn \& Watman, 198129). However, as with all genre instantiations, the actual effect upon the receiver will not always be the one intended by the threatener. We usually know the effect by observing the uptakes - the responses and reactions - to an utterance, both by the intended receiver and by a host of other interlocutors (Freadman, 2002). "No genre can do more than predict the kind of uptake that would make it happy, and no speaker or writer can completely secure an uptake" (Freadman, 2012, p. 560). This aspect is very clear in the below example of a threat that the sender purportedly meant as a joke:

- Jeg bliver den næste school shooter guys, LMAO, watch out3o 'I'll be the next school shooter guys, LMAO, watch out'

The threat, however, had several unwelcome uptakes for the young girl who wrote it. 1) It was reported to the police, 2) she was met by armed law enforcement the next morning who 3 ) forced her to the ground, and 4) arrested her. Ultimately, 5) the case ended up in court. The threat also had a socially very unwelcome uptake, namely that 6) she was expelled from school. However, for her, a welcome uptake was that 7) she was found 'not-guilty' in the case, 8) not because the judges thought that it was not 'objectively an illegal threat', ${ }^{31}$ but 9) because they believed that she meant it as a joke, which 10) some of her friends had also taken it up as. $3^{2}$

\footnotetext{
${ }^{28}$ What Limberg and others call conditional threats and Muschalik calls manipulative threats. 29 Both are studies from the field of social psychology.

${ }^{30}$ Instagram message, published by The Danish Broadcasting Corporation, $D R$ who also broadcasted the trial.

${ }^{31}$ From $D R$ broadcast (Danish: ikke fordi der ikke er tale om en objektivt set strafbar trussel). ${ }^{32}$ Further particulars of the case will not be discussed here.
}

M. Bojsen-Møller, S. Auken, 
As such, there are many examples of unwelcome uptakes on threats: for manipulative threats, an unwelcome uptake could be noncompliance with the directive, and for a retaliative threat, an unwelcome uptake could be laughter. A category of unwelcome uptakes to threats is the purview of an uptake community not intended as the receiver, namely the legal system. Threats can be illegal in themselves if they clash with the legislation of the country or jurisdiction regulating them. In these cases, an extremely unwelcome uptake will be an uptake by police and courts. This is the reason why uptake is such an important notion in understanding threats. The possible uptakes by law enforcement and the legal system create a need for concealment on the part of threateners (although some are oblivious to this need), concealment by indirectness and avoidance of typical traits of threats. As uptake is a notion of generic boundary, it is safer for a threatener to attempt to form an utterance that resembles or mimics (Freadman, 2002) another genre - a promise, a warning, a joke, or merely a statement - so they can plausibly argue that it was not a threat and possibly counter the recognizability of threats.

\section{Recognizing the Social Action of Threats}

One fundamental uptake of a genre consists in other people recognizing the genre, most manifestly by naming or 'labelling' it (Nyboe, 2016). "When a type of discourse or communicative action acquires a common name within a given context or community, that's a good sign that it's functioning as a genre" (Miller \& Shepherd, 2004, p. 1). We have seen that threats are recognized and taken up by law enforcement, judicial systems, scholars who examine threats, and by victims of threats; as such, threats are evidently a recognizable genre for those specific uptake communities. To examine whether threats are a genre that average language users recognize, we conducted a survey with seventeen short text excerpts (test items) that the respondents were instructed

M. Bojsen-Møller, S. Auken,
A. J. Devitt \& T. K. Christensen
$28 / 53$
Sakprosa.no 
to categorize (see Appendix A and B). Four of the test items were chosen because they had been characterized as threats elsewhere.33 The remaining thirteen consisted of different genres, functioning as fillers to ensure that respondents did not realize that this was a survey about threats.

The first three texts they were instructed to categorize in the survey (an invitation, a newspaper headline, and a recipe) had multiple-choice answers to assist respondents in understanding what kind of categorization we were looking for, without presenting the words 'genre' or 'threat'. The remaining texts, including the four threats, had free-text response format, which means there were no other restrictions beside a maximum length of 150 characters.

The four authentic threats (below) were chosen in order to exemplify indirect (1 and 2) and direct (3 and 4 ) threats:

(1) Jeg ved hvor du bor 34

'I know where you live'

(2) Du kommer til at fortryde at du ikke ville snakke35

'You're going to regret that you didn't want to talk'

\footnotetext{
33 They were either called 'threats' in Engelhardt and Lund (2008, 2009) or in court judgments found in Karnov.

34 From typewritten note, Engelhardt \& Lund, 2008. We chose this indirect threat, because there is no mention of either future act, harm or sender responsibility, and because we suspect this to be a formulaic way of threatening.

35 From text message, Karnov. We chose this indirect threat because so much has to be inferred in order for it to be understood as a threat. There is no mention of sender responsibility and no direct mention of harm besides what we can infer from fortryde 'regret'; only futurity is mentioned through kommer til 'going to'.
}

M. Bojsen-Møller, S. Auken, 
(3) Kom med alle sedlerne eller jeg skyder. 36 'Get me all the notes or I'll shoot'

(4) Vi kommer og slår dig ihjel mandag aften 37

'We're coming to kill you Monday night'

We included four different threats to allow us to test whether respondents would recognize them all as threats in spite of their differences in form. We purposely presented all test items without any context in order for us to test how respondents would categorize them without situational factors directing their interpretation. Even though people recognize genres by the contexts in which they typically function, genre knowledge "is often tacitly acquired [...] deeply remembered and affective, and quite durable, connected not only to memories of prior, habitual responses to a genre, but also memories of prior engagements with other, related genres" (Bawarshi \& Reiff, 2010, p. 86). While people ordinarily recognize and take up genres in a context rich with other cues to the nature and category of the genre, it is of particular interest whether the form of some common instantiations of threats is part of people's tacit knowledge. This is of import not only because threats occur in many situations and across different modalities but also because indirect threats can be reconstrued as other, more benign, genres given a shift in context. For instance, the utterance "Look over your shoulder" can be a threat in some circumstances but a warning in others, depending on whether the speaker has the addressee's best interests at heart. Since the status of an utterance as a threat is likely to be disputed, it is important to learn whether the words and sentences used to convey typical forms of threats are recognizable to people,

\footnotetext{
${ }^{36}$ From handwritten note, Engelhardt \& Lund, 2009. This direct threat was chosen because aside from being direct, it is also conditional. Both sender responsibility, harm, and futurity is explicitly mentioned.

37 From handwritten note, Engelhardt \& Lund, 2009. We chose this threat because it is direct, but not conditional. Both sender responsibility, harm, and futurity is explicitly mentioned.
}

M. Bojsen-Møller, S. Auken, 
even without context. In order for a genre to function, it is imperative that it is recognized, and genres will therefore always rely on a common cultural, historical knowledge. We wanted to test the respondents' tacit knowledge of the genre, not merely their recognition of specific situations.

Respondents were approached through a variant of the snowball sampling technique where we recruited acquaintances, friends, colleagues, students, and family members to give the survey to groups in their network that had no prior knowledge of what the study was about. This sampling technique does not ensure random distribution $3^{8}$ but nonetheless, the 111 Danish respondents distribute fairly widely along the parameters gender, 39 age groups, 40 and different educational levels. ${ }^{41}$ We instructed the distributors that they could only tell the prospective respondents that the survey was about categorizing the test items, without mentioning threats. This procedure appears to have been successful, since all 111 respondents were asked at the end of the survey what they thought the survey was about. Only 7 of them included the Danish word for either 'threat' or 'threaten' in their answers.

As mentioned, all of the test items were presented without any context, and furthermore, two of the four threats were indirectly phrased. Nevertheless, results show a high degree of recognition in terms of labelling them as threats: The word trussel 'threat' was included in 70\% (threat 1) and 59\% (threat 2) of the answers for the two indirect threats and in 81\% (threat 3) and 94\% (threat

\footnotetext{
${ }^{38}$ Snowball sampling has the disadvantage that it might "quickly skew to one type of group, clique, or demographic", and it was therefore important for us to ensure that our initial group of distributors were demographically diverse in order to maximize variation (Tracy, 2013, p. 136).

39 Men: $47 \%$, women: $53 \%$, other: $0 \%$.

${ }^{40} 15-17$ years: $25 \%$. $18-29$ years: $14 \%$. $30-44$ years: $20 \%$. $45-59$ years: $24 \% .60-74$ years: $15 \%$. $75+$ years: $2 \%$.

${ }^{41}$ Highest educational level attained: primary and lower secondary school: 29\%. Upper secondary education: $11 \%$. Short-cycle higher education: $21 \%$. Long-cycle higher education (equivalent to a college degree): $39 \%$.
}

M. Bojsen-Møller, S. Auken, 
4) of the answers for the two direct threats. The difference between the two groups, direct and indirect threats, is statistically significant $\left(\chi^{2}(1, N=111)=\right.$ $31.82, p<$.01. Yates' continuity correction applied). ${ }^{42}$ The direct threats were more likely to be categorized as threats than the indirect threats. This is not surprising since indirect threats will often be dependent on contextual factors in order to be interpreted as threats. The utterance respondents labelled most frequently as something other than a threat was number 2: 'You're going to regret that you didn't want to talk', which is also the most indirectly-phrased of the four.

All four threats, however, had a high percentage of answers that only included the one word trussel 'threat' (going from threat 1 to 4 , the percentages are: $57 \%, 47 \%, 68 \%$, and $83 \%$ ), even though respondents were free to write whatever came to mind. The results of the survey show a high degree of consensus on the genre label 'threat', despite differences in form of the four threats. This indicates a broad understanding among average Danish language users of threats as a recognizable genre that can take different forms. However, it is important to consider whether labelling a genre is the same as recognizing the social act or situation of a genre. Many aspects enter into our understanding of a genre situation. When contextual features are left out, as we deliberately did in our survey, in order to examine how recognizable threats are without context, we are obviously creating more room for interpretation than there would have been if we had described the situational factors. Interestingly, this lack of information seems to have prompted respondents to provide fairly detailed descriptions of their categorizations. For example, one respondent categorized threat 1 as 'Information or fear-inducing verbal

\footnotetext{
${ }^{42}$ Since there are only two indirect threats and two direct threats in the survey, it is not possible to draw any clear conclusions from these findings. However, including more threats in the survey would either have made it too obvious that the survey was about threats or would have made the survey too long.
}

M. Bojsen-Møller, S. Auken, 
attack', which does not include the word 'threat', but shows a very astute interpretation of what the situation behind the words might mean. In the same way, some of the responses to the indirect threats pointed out that the test items could mean different things dependent on the context. This, we would argue, is not merely labelling a genre but recognizing the possible situation of the genre.

The survey results indicate that knowledge of genres must go beyond both specific forms and specific contexts. Since our respondents were given four different forms and no context, they did not simply recognize a specific form or context; they must have invoked an entire situation from each genre instantiation. They supplied their own tacit knowledge - their own intricate and intrinsic social and cultural knowledge - and from that, they must have perceived a recurrence, which created the recognition. Some did envision other genre situations, for example, mere statements or jokes, but an overwhelming number did perceive them as threats. One respondent wrote 'usually a joke' and another 'threat/joke/depending on context' for threat 1 , and two other categorized threat 4 as 'joke' and 'humor'. Actually, this kind of uptake may very well indicate just how recognizable the genre of threats is, since ironically, they must be recognizable as threats before they can be parodied and hence taken as jokes. 43 Therefore, despite the fact that threats do not emerge from a shared discourse community or community of practice, our survey indicates that there is a more common cultural knowledge of threats. We agree with Miller et al. that genres are "motivated by shared recognitions of shared exigences, however imperfectly delineated" (Miller et al., 2018, p. 270). We therefore interpret this shared recognition of threats as

43 In this way, some types of jokes "exploit our knowledge of serious genres and activity types (thereby relying on it [red. our knowledge])" (Kotthoff, 2007, p. 263). The interesting issue of threats that are intended as and/or taken up as jokes will not be discussed further in this article.

M. Bojsen-Møller, S. Auken, 
also being an intrinsic recognition of the shared exigence and function of threats, i.e. intimidation and exerting power over someone else. The fact that threats have strong affective connotations of fear, coercion, and violence, have the possibility of being carried out, and are seen as antisocial and in some circumstances illegal only heightens the recognizability of the genre.

\section{Threats as an Illicit Genre}

Most studies within RGS have been conducted on specific data types, by concrete instantiations of a particular genre. These data types have mostly come from institutional or at least socially accepted genres (e.g. Bazerman, 1994; Paré, 2002; Schryer, 1993; Winsor, 2000), and consequently, RGS theory is mostly informed by these types of genres. In a recent review of the types of genres studied within RGS, Miller (2017) lists the following four categories:

1) marketed or commercial genres,

2) administered genres,

3) institutional genres, and

4) vernacular genres. 44

We propose the addition of a fifth category, namely illicit genres that include such genres as threatening communications, hate messages, harassment, defamation, bullying, grooming and slander. These genres do not have an institutional setting; we do not learn how to use them in school, and we cannot study their structure in a textbook. They do not emerge from a shared,

44 Marketed or commercial genres are e.g. found in literary, film or television settings. Administered genres are e.g. found in governmental, educational or organizational settings. Institutional genres are e.g. found in science, religious or journalistic settings. Vernacular genres can be e.g. personal blogs, fan-fiction, or sticky notes.

M. Bojsen-Møller, S. Auken, 
coherent discourse community (though some of the illicit genres may be more commonly used in some discourse communities or communities of practice than in others 45 ), and they are generally not accepted in society. There is a strong consensus in many different parts of many different societies to view the use of them as unwanted and unacceptable behavior. They function widely across cultures as illicit, because of traditional, as to some of the genres ancient, ${ }^{46}$ norms and values surrounding the individual's inviolability. That these are pervasive norms and values is mirrored by the fact that many of the genres are taken up as illegal acts by different legal systems spanning multiple countries.

Of the four categories that Miller lists (above), the vernacular genres are the genres that have most in common with illicit genres, since neither of these two categories have commercial or institutional settings. The vernacular genres are less dictated by institutional regulations than all of the other three categories on Miller's list are, particularly the administered and institutional genres. The administered genres are "imposed, or dictated, sometimes defined by law or regulation" (Miller, 2017, p. 24). The institutional genres are similar to the administered genres, but their regulations are more implicit because they are based on traditions and (sometimes strong) social conventions. The greatest difference between the vernacular genres and the illicit genres is that, while the vernacular genres have to do with genres that "emerge and survive

\footnotetext{
45 Because of their often occluded nature, it is difficult to get an overview of the communities of practice that do not deem these genres illicit, but actually use them. When it comes to threats, we do know of certain communities of practice (in Denmark, there has for example been a hidden group on Facebook calling themselves Offensimentum. They practiced bullying and threatening as a shared interest and identity, but most often, it is individuals who threaten as a personal and not as a shared venture. There are also hidden child sex abuse fora on the dark web that share child pornography and discuss grooming techniques, and within these communities of practice, the participants themselves do not see their actions as illicit or unacceptable (Grant, 2019), even though they are aware that large parts of society deem them illicit and sanction them socially, societally and legally.

${ }^{46}$ For example, in several of the medieval Icelander's Sagas, the word 'nid' was used for types of speech that were defamatory - that in some way challenged the honor of another person which was a serious misdeed.
}

M. Bojsen-Møller, S. Auken, 
when a community finds a configuration of features that satisfies or pleases those who interact together, addressing some communally recognized exigence" (Miller, 2017, p. 25), the illicit genres are the exact opposite. They are genres that displease society, and, worse, they generally not only displease but also hurt those who are the targets of them. They are neither constructive, edifying, nor knowledge-building (Tønnesson, 2012; 2017), and instead of supporting societal or democratic processes, they are believed to have the ability to undermine them.

In other words, the difference between illicit genres and other genres is that illicit genres are socially proscribed. They will therefore often be communicated secretly, anonymously or indirectly. It is important to acknowledge that silences or implicitness can be used as strategic moves in genres as well as explicitness can, since "genres are defined as much by what they exclude as what they include" (Randazzo, 2015, para. 1) and since people can "use silence to protect themselves or gain agency" (Randazzo, 2015, para. 12). Also, occlusion plays a bigger role in the illicit genres than in most other genres, because the users of the illicit genres often wish to distance themselves from the illicit act. This can for instance be done by being indirect, by sending them anonymously, by giving their utterance a different genre label (as underlined in example (1) below), or simply by negating the genre, namely by antilabelling it (as underlined in example (2) below):

(1) DU HAR TIDLIGERE FÅET EN ADVARSEL SOM DENNE: DETTE ER DEN SIDSTE. NASTE GANG SKYDER VI DEN TVAERS GENNEM DIT TYKKE HOVED. 'YOU WERE GIVEN A WARNING LIKE THIS BEFORE: THIS IS

M. Bojsen-Møller, S. Auken, 


\section{THE LAST ONE. NEXT TIME WE WILL SHOOT IT RIGHT} THROUGH YOUR FAT HEAD.' 47

(2) Ville onske at jeg bare kunne udfordrer dig til duel. Tage dig ud med et enkelt skud (Dette er ikke en konkret trussel din nasserøv) 'Wish I could just challenge you to a duel. Take you out with a single shot (This is not a concrete threat you deadbeat)' 48

The anti-labelling of the genre in example (2) constitutes a metadiscursive disavowal of the genre. These tactics of giving different labels to or antilabelling a genre can have a practical explanation since admitting to the use of an illicit genre carries risks of being sanctioned by different uptake communities in society, the legal system being the most poignant. Consequently, instead of it being the users who name the genres, the illicit genres will often be named by their receivers and victims and by secondary audiences, namely (often incidental) purviewers to the utterances, police or judicial system. Genre labels are a discursive battleground (Auken, 2019), and this fact becomes particularly important when dealing with illicit genres.

Since they are generally not accepted by society, it is unsurprising that many of the illicit genres are also illegal (e.g. many threats, grooming, slander, defamation, offering a bribe). The reasons for a genre's illegality will obviously vary from genre to genre but the common denominator is the negative effect the genre has on either the receiver of the genre (threats, grooming, slander, defamation) or on societal functions (bribery, perjury). Although not all illicit genres or instantiations of illicit genres are illegal (e.g. some hate messages ${ }^{49}$ ), the illicit genres that are illegal have a different possible uptake than the legal

47 From letter, Engelhardt \& Lund, 2008.

48 From Facebook message sent to Danish politician.

49 Though hate messages targeted at minority groups are illegal in most countries.

M. Bojsen-Møller, S. Auken,
A. J. Devitt \& T. K. Christensen
$37 / 53$
Sakprosa.no 
ones. The difference is simply that the illegal ones are taken up by a specific uptake community: the judicial system. They are described - and sometimes even labelled - as illegal acts in legislation (differing from jurisdiction to jurisdiction). This means that police will take up instantiations of these illicit genres as illegal acts, lawyers will argue whether they are sufficiently clear instantiations of the category described in legislation, and judges will decide on the very same issue.

\section{Conclusion}

Since $R G S$ has not been extended to this type of genre, it is to be expected that different types of questions will arise compared to the ones asked when dealing with data from genres that are taught in schools or used in everyday, sociable communication. Illicit genres both confirm and complicate some RGS claims. Society in general does not accept illicit genres because of their negative exigencies, functions, and effects, which is consistent with RGS defining genres by exigences and functions. Bakhtin's (1986a) notion that a defining character of a genre is its type of addressivity is also extremely useful for analyzing threats and other illicit genres, since the effect of an illicit genre on its victim(s) is often the cause for it becoming illicit in large parts of many societies.

We emphasize the fact that form is important to assess in genres since recurring patterns in form is a big part of what creates recognizability. However, with illicit genres, the most recognizable forms, the ones that most clearly and explicitly convey their meaning, may sometimes be occluded because of a greater need for tactical indirectness and silence than for explicitness. This heightens Randazzo's claim that genres are defined as much by the things they exclude as by the things they include (Randazzo, 2015), and underlines the importance of silences and exclusions in genres.

M. Bojsen-Møller, S. Auken, 
In the case of threats, their forms are extremely heterogeneous, but threat scholars have found some formal traits to be typical of threats, for example futurity, indication of harm, and sender responsibility. People have ideologies about what threats look like; some are consistent with what scholars have found in real data, while others diverge from it. The ideologies are, however, still part of what people associate with threats, which is important when trying to understand how a genre functions and is taken up in society. Recurrence itself is not merely a matter of repeating traits; it is also a matter of perception by language users. Recognizability must be evidence of perceived recurrence, which is why we sought to test the recognizability of different threats through a survey. The results of the survey appear to confirm that people recognize genres, either by labelling them or by describing their situation, but this requires further testing. Since we asked our respondents to categorize several different forms of threats, without giving them contextual information, the study substantiates the notion that genre knowledge is tacitly stored (Freedman, 1994), and not only connected to the recognition of specific forms or derived from specific contexts. It is evidence that people recognize genres by invoking a context from their general cultural and social knowledge. It is known that specific communities can often recognize and label the genres that they themselves use (e.g. Devitt, 1991), but our survey indicates that this tacit knowledge might indeed be broader and inclusive of more than specific, delimited communities. It suggests that tacit knowledge may transcend different communities and be inclusive of wider cultures and societies.

Illicit genres are generally unwelcome in society, and every distinguishing quality that they have comes from that. The uptakes of illicit genres have a different character than the uptakes of other genres: in the forms of sanctions and condemnations by society, law enforcement, and judicial system. The very possibility of this kind of uptake influences the illicit genres themselves, because most often the people who use them will not openly admit to having

M. Bojsen-Møller, S. Auken,
A. J. Devitt \& T. K. Christensen
$39 / 53$
Sakprosa.no 
used them. Instead, the uptake communities are the ones who name and describe the genres. We agree with Freadman (2012) that uptakes can be either expected or unexpected, welcome or unwelcome, but when it comes to the illicit genres, the nature of the unwelcome uptakes has such an immense impact on the ones producing them that they become even more important for our understanding. The illicit genres have the dual addressivity of having to contemplate both their desired uptake and their undesired uptake, and this affects the genres.

In the case of threats, the manipulative threats (that have a directive as well as a commissive illocutionary force) will have to consider both the desired uptake of their victims (that they do what is asked of them) and the prospect of undesired uptakes (sanctions). The retaliative threats (that have no directive quality) tend to be more direct and more explosive, since they will often come out of frustration or anger. As they tend to be more direct and seem less thought-through, they also tend to have more difficulties invoking plausible deniability. An attempted occlusion will then often happen afterwards in a kind of backtracking, for example by the threatener's distancing themselves from the specific propositional content of their threat:

by underlining aspects that they think indicate that they did not have the legally required intent to threaten ('I said I could do it. I didn't say I was going to do it');

by evaluating their own statement so it can be seen in a different light ('I would never do anything like that');

by commenting on what they really meant ('I was just frustrated');

by anti-labelling it ('it was not a threat');

M. Bojsen-Møller, S. Auken,

A. J. Devitt \& T. K. Christensen 40 / $53 \quad$ Sakprosa.no 
or by calling it something else, a non-illicit genre ('it was a joke'5o).

Illicit genres are not regulated in the same way as genres that are accepted by society are. In contrast to the institutional and administered genres that try to comply with regulation, they appear in spite of regulation, e.g. laws prohibiting their usage or societal norms of ethical or proper conduct. Illicit genres may test the boundaries of regulation, but they are still highly influenced by the regulations that oppose them. This type of regulation influences their form in the reverse way than regulation of institutional genres does; they will more often try to avoid the forms that are associated with the genre, while still attempting to achieve their aim.

\section{References}

Artmann, P. (1996). Tätertexte. eine linguistische Analyse der Textsorten Erpresserbrief und Drohbrief. [Texts by Offenders. a linguistic Analysis of the Text Types Blackmail Letter and Threat Letter] (Doctoral dissertation). JuliusMaximilians-Universität zu Würzburg, Würzburg, Germany.

50 These examples draw on Danish field notes conducted during observations of Danish threat trials. The examples serve to provide perspective to the analysis, but they will not be treated further here.

M. Bojsen-Møller, S. Auken, 
Auken, S. (2015). Utterance and function in Genre Studies: A literary perspective. In J. Anderson \& J. Mai (Eds.), Genre theory in Information Studies (vol. 11, pp. 155-178). Bingley, United Kingdom: Emerald Group Publishing Limited. doi:10.1108/S2055-537720140000011009

Auken, S. (2018). Understanding genre. Journal of Zhejiang International Studies University, 3(2), 14-27. Retrieved at http://zjjyxyxb.paperonce.org/oa/pdfdow.aspx?Sid=20180203

Auken, S. (2019, November). Summing up. In T. K. Christensen \& M. BojsenMøller (Chairs), Illicit genres. Symposium conducted at Department of Nordic Studies and Linguistics, University of Copenhagen, Denmark.

Austin, J. L. (1962). How to do things with words. London, United Kingdom: Oxford University Press.

Bakhtin, M. M. (1986a). The problem of speech genres. In C. Emerson \& M. Holquist (Eds.), V. W. McGee (Trans.), Speech genres and other late essays (pp. 60-102). Austin: University of Texas Press.

Bakhtin, M. M. (1986b). The problem of the text. In C. Emerson \& M. Holquist (Eds.), V. W. McGee (Trans.), Speech genres and other late essays (pp. 103131). Austin: University of Texas Press.

Bawarshi, A., \& Reiff, M. J. (2010). Genre: An introduction to history, theory, research, and pedagogy. Fort Collins, CO: The WAC Clearinghouse.

Bazerman, C. (1994). Systems of genres and the enactment of social intentions. In A. Freedman \& P. Medway (Eds.), Genre and the new rhetoric, (pp. 79-101). London, United Kingdom: Taylor \& Francis.

M. Bojsen-Møller, S. Auken,
A. J. Devitt \& T. K. Christensen
$42 / 53$
Sakprosa.no 
Bazerman, C. (2004) Speech Acts, Genres, and Activity Systems: How Texts Organize Activity and People. In C. Bazerman \& P. Prior (Eds.), What Writing Does and How It Does It: An Introduction to Analyzing Texts and Textual Practices (pp. 309-339). London, United Kingdom: Routledge.

Bitzer, L. (1968). The rhetorical situation. Philosophy \& Rhetoric, 1(1), 1-14.

Buckels, E., Trapnell, P., \& Paulhus, D. (2014). Trolls just want to have fun. Personality and Individual Differences, 67, 97-102. doi:10.1016/j.paid.2014.01.016

Christensen, T. K. (2007). Hyperparadigmer - en undersøgelse af paradigmatiske samspil i danske modussystemer. [Hyperparadigms - an investigation of paradigmatic interplay in Danish mood systems]. (Doctoral dissertation). Roskilde University, Roskilde, Denmark.

Christensen, T. K. (2019). Indirect threats as an illegal speech act. In K. Ramshøj Christensen, J. Wood \& H. Jørgensen (Eds), The Sign of the $V$. Papers in Honour of Sten Vikner Festschrift 113-130. Aarhus, Denmark: Aarhus University.

Christensen, T. K., \& Bojsen-Møller, M. (2018). Vi ved hvor du bor...Truslen som sproghandling og genre. [We know where you live...Threats as speech act and genre]. Mål Og Mæle, 39(3), 25-30.

Christensen, T. K., \& Bojsen-Møller, M. (2019). Sproglige virkemidler i indirekte trusler. [Linguistic techniques in indirect threats]. In Y. Goldshtein, I. Schoonderbeek Hansen \& T. T. Hougaard (Eds.), Møde om Udforskningen af Dansk Sprog 17 (pp. 207-226). Aarhus, Denmark: Aarhus University.

The Danish Broadcasting Corporation, DR (https://www.dr.dk/).

M. Bojsen-Møller, S. Auken,

A. J. Devitt \& T. K. Christensen $43 / 53 \quad$ Sakprosa.no 
Devitt, A. J. (1991). Intertextuality: Generic, referential and functional. In: C. Bazerman \& Paradis (Eds.), Textual dynamics of the professions: Historical and contemporary studies of writing in professional communities (pp. 33657). Madison: University of Wisconsin.

Devitt, A. J. (2004). Writing genres. Carbondale: Southern Illinois University Press.

Devitt, A. J. (2009). Re-fusing form in genre study. In J. Giltrow \& D. Stein (Eds.), Genres in the Internet: Issues in the theory of genre (pp. 27-48). Amsterdam, Netherlands: John Benjamins Publishing Company.

Devitt, A. J. (2016). Uncovering occluded publics: Untangling public, personal, and technical spheres in jury deliberations. In A. Bawarshi \& M. J. Reiff (Eds.), Genre and the performance of publics. Boulder, CO: Utah State University Press.

Engelhardt, R., \& Lund, C. (2008). Jeg er bevæbnet og har tømmermænd. Udvalgte trusselsbreve fra Rigspolitiets Arkiv. [I'm armed and hungover. Selected threat letters from the Danish National Police Archives]. Copenhagen, Denmark: People's Press.

Engelhardt, R., \& Lund, C. (2009). Jeg tager bomben med når jeg går. Udvalgte trusselsbreve m.m. fra Rigspolitiets Arkiv. [I'll take the bomb with me when I leave. Selected threat letters etc. from the Danish National Police Archives]. Copenhagen, Denmark: People’s Press.

Fraser, B. (1998). Threatening revisited. International Journal of Speech Language and the Law , 5, 159-173. doi:10.1558/sll.1998.5.2.159

M. Bojsen-Møller, S. Auken, 
Freadman, A. (1994). Anyone for tennis. In A. Freedman \& P. Medway (Eds.), Genre and the new rhetoric (pp. 43-66). London, United Kingdom: Taylor \& Francis.

Freadman, A. (2002). Uptake. In R. Coe, L. Lingard \& T. Teslenko (Eds.), The rhetoric and ideology of genre, strategies for stability and change (pp. 3953). Cresskill, NJ: Hampton Press.

Freadman, A. (2012). The traps and trappings of genre theory. Applied Linguistics, 33, 544-563. doi:10.1093/applin/amso5o

Freadman, A. (2020). Reflections on 'genre as social action'. Canadian Journal for Studies in Discourse and Writing/Redactologie. Forthcoming.

Freedman, A. (1994). Do as I say: The relationship between teaching and learning new genres. In A. Freedman \& P. Medway (Eds.), Genre and the new rhetoric (pp. 191-210). London, United Kingdom: Taylor \& Francis.

Freedman, A., \& Medway, P. (Eds.). (1994). Genre and the new rhetoric. London, United Kingdom: Taylor \& Francis.

Fuller, P. B. (2015). Evaluating intent in true threat cases: The importance of context in analyzing threatening Internet messages. Hastings

Communications and Entertainment Law Journal, 37, 37-78. Retrieved from https://repository.uchastings.edu/hastings comm ent law journal/vol37/is $\underline{\mathrm{s} 1 / 2}$

Gales, T. A. (2010). Ideologies of violence: A corpus and discourse analytic approach to stance in threatening communications. (Doctoral dissertation). University of California, Davis.

M. Bojsen-Møller, S. Auken,
A. J. Devitt \& T. K. Christensen
$45 / 53$
Sakprosa.no 
Gales, T. A. (2011). Identifying interpersonal stance in threatening discourse: An appraisal analysis. Discourse Studies, 13, 27-46.

doi:10.1177/1461445610387735

Gales, T. A. (2015a). The stance of stalking: A corpus-based analysis of grammatical markers of stance in threatening communications. Corpora, 10 , 171-200. doi:10.3366/cor.2015.0073

Gales, T. A. (2015b). Threatening stances: A corpus analysis of realized vs. non-realized threats. Language and Law / Linguagem e Direito, 2(2), 1-25. Retrieved from https://ler.letras.up.pt/uploads/ficheiros/14124.pdf

Gingiss, P. (1986). Indirect threats. Word, 37, 153-158.

doi:10.1080/00437956.1986.11435774

Grant, T. (2019, November). Genres and communities of practice in online sex abuse fora. In T. K. Christensen \& M. Bojsen-Møller (Chairs), Illicit genres. Symposium conducted at Department of Nordic Studies and Linguistics, University of Copenhagen, Denmark.

Grepstad, O. (1997). Det litterære skattkammer: sakprosaens teori og retorikk. [The literary treasury: the theory and rhetoric of non-fiction]. Oslo, Norway: Det Norske Samlaget.

de Groot, E. B. (2008). English annual reports in Europe: A study on the identification and reception of genre characteristics in multimodal annual reports originating in the Netherlands and in the United Kingdom. Utrecht, The Netherlands: LOT.

M. Bojsen-Møller, S. Auken,

A. J. Devitt \& T. K. Christensen $46 / 53 \quad$ Sakprosa.no 
Harder, P. (2006). Dansk Funktionel Lingvistik. [Danish Functional Linguistics]. NyS, Nydanske Sprogstudier, 34, 92-130.

doi:10.7146/nys.v34i34-35.13459

Hurt, M., \& Grant, T. (2019). Pledging to harm: A linguistic appraisal analysis of judgment comparing realized and non-realized violent fantasies. Discourse and Society, 3o, 154-171. doi:10.1177/0957926518816195

Karnov. (https://www.karnovgroup.dk/loesninger/jura).

Kent, G. (1967). The effects of threats. Columbus: Ohio State University.

Kotthoff, H. (2007). Oral genres of humor: On the dialectic of genre knowledge and creative authoring. Pragmatics, 17, 263-296.

Larsen, P. H. (1973). Om “offentligt at tilskynde til forbrydelse”. En studie i forholdet mellem sprog, jura og politik. [On "public incitement to crime”. A study of the relationship between language, law and politics]. Nydanske Sprogstudier, 5, 5-39. doi:10.7146/nys.v5i5.10339

Limberg, H. (2009). Impoliteness and threat responses. Journal of Pragmatics, 41, 1376-1394. doi:10.1016/j.pragma.2009.02.003

Milburn, T. W., \& Watman, K. H. (1981). On the nature of threat: A psychological analysis. New York, NY: Praeger Publishers.

Millar, S. (2019). Hate speech: Conceptualisations, interpretations and reactions. In M. Evans, L. Jeffries \& J. O'Driscoll (Eds.), The Routledge Handbook of Language in Conflict (pp. 145-163). Abingdon, Oxon: Routledge. doi:10.4324/9780429058011-9

M. Bojsen-Møller, S. Auken,
A. J. Devitt \& T. K. Christensen 
Miller, C. R. (1984). Genre as social action. Quarterly Journal of Speech, 70, 151-167. doi:10.1080/00335638409383686

Miller, C. R. (2015). Genre change and evolution. In N. Artemeva \& A. Freedman (Eds.), Genre studies around the globe, beyond the three traditions (pp. 154-185). Lexington, KY: Trafford Publications.

Miller, C. R. (2017). Where do genres come from? In C. R. Miller \& A. Kelly (Eds.), Emerging Genres in New Media Environments (pp. 1-34). Cham, Switzerland: Springer International.

Miller, C. R., Devitt, A. J., \& Gallagher, V. J. (2018). Genre: Permanence and change. Rhetoric Society Quarterly, 48, 269-277.

doi:10.1080/02773945.2018.1454194

Miller, C. R., \& Shepherd, D. (2004). Blogging as social action: A genre analysis of the weblog. In L. Gurak, S. Antonijevic, L. Johnson, C. Ratliff \& J. Reymann (Eds.), Into the blogosphere: Rhetoric, community, and the culture of weblogs (pp. 1-21). Minneapolis: University of Minnesota Libraries.

Mortensen, J. (2012). Subjectivity and intersubjectivity as aspects of epistemic stance marking. In N. Baumgarten, I. Du Bois \& J. House (Eds.), Subjectivity in language and in discourse (pp. 229-246). Leiden, Netherlands: Brill.

Muschalik, J. (2018). Threatening in English: A mixed method approach. Amsterdam, Netherlands: John Benjamins Publishing Company.

Napier, M., \& Mardigian, S. (2003). Threatening messages: The essence of analyzing communicated threats. Public Venue Security, September/October, 16-19.

M. Bojsen-Møller, S. Auken,

A. J. Devitt \& T. K. Christensen 48 / $53 \quad$ Sakprosa.no 
Nielsen, P. J. (2011). Kongruenskonstruktion i dansk - en syntaktisk analyse af indhold og udtryk. [Concord construction in Danish: A syntactic analysis of content and expression]. Oslo, Norway: Novus Forlag.

Nilsen, A. B. (2014). Hatretorikk: Den intolerante språkbruken. [Hate speech: The intolerant language]. FLEKS-Scandinavian Journal of Intercultural Theory and Practice, 1(1), 1-16. doi:10.7577/fleks.839

Nini, A. (2017). Register variation in malicious forensic texts. The International Journal of Speech, Language and the Law, 24, 99-126. doi:10.1558/ijsll.30173

Nyboe, J. (2016). The game of the name: Genre labels as genre and signature. Scandinavian Studies, 88, 364-392.

doi:10.5406/scanstud.88.4.0364

Olsson, J. (2004). Forensic linguistics: An introduction to language, crime and the law. London, United Kingdom: Continuum.

Palmer, F. R. (2001). Mood and modality (Second edition.). Cambridge, United Kingdom: Cambridge University Press.

Paré, A. (2002). Genre and identity: Individuals, institutions, and ideology. In R. Coe, L. Lingard \& T. Teslenko (Eds.), The rhetoric and ideology of genre, strategies for stability and change (pp. 57-71). Cresskill, NJ: Hampton Press.

Pinker, S., Nowak, M. A., \& Lee, J. J. (2008). The logic of indirect speech. Proceedings of the National Academy of Sciences, 105, 833-838. doi:10.1073/pnas.0707192105

M. Bojsen-Møller, S. Auken, A. J. Devitt \& T. K. Christensen 49 / $53 \quad$ Sakprosa.no 
Pogner, K. H. (2005). Discourse communities and communities of practice on the social context of text and knowledge production in the workplace. Paper presented at the 21st EGOS Colloquium, Berlin, Germany.

Randazzo, C. (2015). Hearing silence: Toward a mixed-method approach for studying genres' exclusionary potential. Composition Forum, 31. Retrieved from https://compositionforum.com/issue/31/hearing-silence.php

Reiff, M. J., \& Bawarshi, A. (2011). Tracing discursive resources: How students use prior genre knowledge to negotiate new writing contexts in firstyear composition. Written Communication, 28, 312-337. doi:10.1177/0741088311410183

Reiff, M. J., \& Bawarshi, A. (Eds.). (2016). Genre and the performance of publics. Logan: Utah State University Press.

Salgueiro, A. B. (2010). Promises, threats, and the foundations of Speech Act Theory. Pragmatics, 20, 213-228. doi:10.1075/prag.20.2.05bla

Schauer, F. (2003). Intentions, conventions, and the First Amendment: The case of cross-burning. Supreme Court Review, 2003, 197-230. Retrieved from http://www.jstor.org/stable/35.36953

Schryer, C. F. (1993). Records as genre. Written Communication, 10, 200234. doi:10.1177/0741088393010002003

Schryer, C. F. (2002). Genre and power: A chronotopic analysis. In R. Coe, L. Lingard \& T. Teslenko (Eds.), The rhetoric and ideology of genre, strategies for stability and change (pp. 57-102). Cresskill, NJ: Hampton Press.

M. Bojsen-Møller, S. Auken, 
Searle, J. R. (1969). Speech acts, an essay in the philosophy of language.

Cambridge, United Kingdom: Cambridge University Press.

Segal, J. Z. (2007). Breast cancer narratives as public rhetoric: Genre itself and the maintenance of ignorance. Linguistics and the Human Sciences, 3, 323. doi:10.1558/lhs.v3i1.3

Shuy, R. (1996). Language crimes, the use and abuse of language evidence in the courtroom. Cambridge, Mass: Blackwell.

Smith, S. (2006). From violent words to violent deeds? Assessing risk from threatening communications (Doctoral dissertation). Georgetown University, Washington, DC.

Smith, J. M. (2019). Intimate partner femicide: Using Foucauldian analysis to track an eight stage progression to homicide. Violence Against Women. doi:10.1177/1077801219863876

Solan, L., \& Tiersma, P. M. (2005). Speaking of crime, the language of criminal justice. Chicago, IL: University of Chicago Press.

Storey, K. (1995). The language of threats. International Journal of Speech Language and the Law, 2, 74-80. doi:10.1558/ijsll.v2i1.74

Swales, J. (2016). Reflections on the concept of discourse community. ASp, 69, 7-19. doi:10.400o/asp.4774

Tracy, S. (2013). Qualitative research methods, collecting evidence, crafting analysis, communicating impact. Chichester, West Sussex, United Kingdom: Wiley-Blackwell.

M. Bojsen-Møller, S. Auken,
A. J. Devitt \& T. K. Christensen
$51 / 53$
Sakprosa.no 
Tønnesson, J. (2012). Hva er sakprosa. [What is non-fiction prose.] Oslo, Norway: Universitetsforlaget.

Tønnesson, J. (2017). Nyere sakprosaforskning i Norge: En kort presentasjon. [Newer research of non-fiction prose in Norway: A short presentation.] Nordisk Tidsskrift for Informationsvidenskab Og Kulturformidling, 2, 29-38. doi:10.7146/ntik.v2i3.25966

Villadsen, L. S. (2017). Doxa, dissent, and challenges of rhetorical citizenship: "When I Criticize Denmark, It Is not the White Nights or the New Potatoes I Have In Mind”. Javnost - The Public, 24(3), 235250. doi:10.1080/13183222.2017.1306191

Walton, D. (1996). Plausible deniability and evasion of burden of proof. Argumentation, 10, 47-58. doi:10.1007/BFo0126158

Walton, D. (2000). Scare tactics, arguments that appeal to fear and threats. Dordrecht, Netherlands: Kluwer Academic Publishers.

Walton, D., \& Macagno, F. (2007). The fallaciousness of threats: Character and ad baculum. Argumentation, 21, 63-81. doi:10.1007/s10503-006-9018-7

Wenger, E., McDermott, R., \& Snyder, W. (2002). Cultivating communities of practice: a guide to managing knowledge. Boston, Mass: Harvard Business School Press.

Winsor, D. (2000). Ordering work: Blue-collar literacy and the political nature of genre. Written Communication, 17(2), 155-184.

doi:10.1177/0741088300017002001

M. Bojsen-Møller, S. Auken,

A. J. Devitt \& T. K. Christensen 52 / $53 \quad$ Sakprosa.no 
Yamanaka, N. (1995). On indirect threats. International Journal for the Semiotics of Law, 8, 37-52. doi:10.1007/BF01677089

M. Bojsen-Møller, S. Auken, 